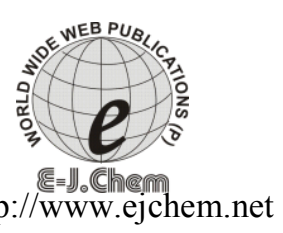

\title{
The Influence of the Chemical Structures of Chitosan and Acid Dye on the Adsorption Process
}

\author{
HAYET BEN ALI ${ }^{\mathrm{a}}$, SALMA BESBES HENTATI ${ }^{\mathrm{b}}$, SALEM S. AL-DEYAB ${ }^{\mathrm{c}}$, MOHAMED $^{\circ}$ \\ RZAIGUI $^{\mathrm{a}}$, AND M'HENNI MOHAMED FAROUK ${ }^{\mathrm{d}}$
}

${ }^{a}$ Laboratoire de Chimie des Matériaux, Faculté des Sciences de Bizerte, Zarzouna 7021, Bizerte, Tunisia

${ }^{\mathrm{b}}$ Laboratoire de Thermodynamique et d'Electrochimie, Faculté des Sciences de Bizerte, Zarzouna 7021, Bizerte, Tunisia

${ }^{c}$ Petrochemical Research Chair, College de Science, King Saud University, Riadh, Saudi Arabia

${ }^{\mathrm{d}}$ Unité de Recherche de Chimie Appliquée et Environment, Faculté des Science de Monastir, 5000, Tunisia

Salma.Hentati@fsb.rnu.tn

Received 05 October 2011; Accepted 03 December 2011

\begin{abstract}
The objective of this paper is the study of the influence of the chemical structures of adsorbent and adsorbate on the adsorption process. By using of crab shell chitosan (CC) and deep-pink shrimp chitosan (CP) for removal of acid 183 and $\mathrm{AR} 114$ from aqueous solutions, it is shown that $\mathrm{CP}$, which corresponds to the highest molecular weight, is the most efficient adsorbent material. In addition, the best extent of decolorization is obtained for AR 183 that is the smallest molecule. Langmuir model represents the best fit of the experimental data, indicating monolayer coverage of chitosan outer surface. Pseudo-second order kinetic model describes accurately the adsorption processes, suggesting chemical rate limiting steps. The positive values of the enthalpy changes indicated endothermic attachment of dyes to the biomaterials. CP/AR183 system corresponds to the most energetically favorable phenomenon. Besides, desorption of AR from chitosan was found to be very low in acidic aqueous medium for all couples.
\end{abstract}

Keywords: Crab shell Chitosan; Deep-pink shrimp shell Chitosan; AR 114; AR183; Adsorption isotherms; Kinetics.

\section{Introduction}

Due to its general interest in environment ${ }^{1-4}$, the adsorption process for the removal of dyestuffs from textile effluents has been the subject of numerous studies. Their adsorption 
onto activated carbon, which is the most efficient and expensive technique, has been widely used $^{5-6}$. The presence of reactive amino groups in chitosan (Fig.1) gave it as a promising adsorbent $^{7-19}$. The efficiency of this biopolymer could be affected by its Molecular weight and its degree of deacetylation ${ }^{4}$.

Several studies have been concerned with the adsorption of Acid dyes onto chitosan ${ }^{1,4,8,16}$. It is noteworthy that the studies of AR183/chitosan and AR 114/chitosan couples have never been reported onto this biomaterial.

The work presented here relates to the investigation of the effect of the chitosan molecular weight as well as the acid dye molecular structure on the adsorption process. We will report the comparative studies of the efficiency of chitosan, which derived from the shell chitin (CC) and the deep-pink shrimp chitin (CP), to remove AR183 and AR114 (Fig. 2) from aqueous solutions. Regarding storing of the modified chitosan, the study of the desorption phenomena of the adherent materials were also examined. The adsorption and desorption processes of AR/PAC couples were also studied.

Table 1. Langmuir isotherm constants of AR/ Adsorbent systems.

\begin{tabular}{ccccc}
\hline Dyes & $\mathrm{Q}_{\max }\left(\mathrm{mg} \mathrm{g}^{-1}\right)$ & $\mathrm{K}_{\mathrm{L}}\left(\mathrm{L} \mathrm{g}^{-1}\right)$ & $\mathrm{a}_{\mathrm{L}}\left(\mathrm{L} \mathrm{mg}^{-1}\right)$ & $\mathrm{SSE}$ \\
\hline $\begin{array}{c}\mathrm{AR} 183 / \mathrm{CC} \\
\mathrm{AR} 183 / \mathrm{CP}\end{array}$ & 347.374 & 14.045 & 0.040 & 0.072 \\
$\mathrm{AR} 183 / \mathrm{PAC}$ & 446.75 & 103.092 & 0.23 & 0.006 \\
& 260.573 & 22.371 & 0.085 & 0.007 \\
$\mathrm{AR} 114 / \mathrm{CC}$ & 327.974 & 17.421 & 0.053 & 0.001 \\
$\mathrm{AR} 114 / \mathrm{CP}$ & 439.8 & 76.335 & 0.173 & 0.001 \\
$\mathrm{AR} 114 / \mathrm{PAC}$ & 250.846 & 22.831 & 0.091 & 0.009 \\
& & & & \\
\hline
\end{tabular}

\section{Experimental}

Chitins were isolated from the crab shell (CC) and deep-pink shrimp shell (CP), respectively. The Corresponding chitosan were prepared by purification and deacetylation of chitins according to literature ${ }^{7}$. By means of FT-IR analysis of $\mathrm{CP}$ and $\mathrm{CC}^{20,21}$, a degree of deacetylation (DD) of about $82 \%$ was determined by Eq. 1 for the two kind of chitosan.

$$
D D=100-\left[\frac{A_{1654}}{A_{3450}}\right] \times 100 / 1.33
$$

Where $\mathrm{A}_{1654}$ and $\mathrm{A}_{3450}$ are the absorbance values of chitosan at $1654 \mathrm{~cm}^{-1}$ and $3450 \mathrm{~cm}^{-1}$, respectytively. The average particles size of Chitosan is $<600 \mu \mathrm{m}$. PAC (particle size $<250$ $\mu \mathrm{m})$ was purchased from Fluka. AR183 and AR114 (Aldrich chemical Co) were used 
without purification. Their maximum wavelengths are 496 and $514 \mathrm{~nm}$, respectively. The effects of the experiment parameters ( $\mathrm{pH}$, concentration, contact time and adsorbent dose) were studied. The $\mathrm{pH}$ of solution was adjusted with $\mathrm{H}_{2} \mathrm{SO}_{4}$ and $\mathrm{NaOH}$ solutions. Equilibrium adsorption isotherms were determined using bath solutions by UV-visible analysis. Adsorbent material $(0.1 \mathrm{~g})$ and $(50 \mathrm{ml})$ of dye $\left(50-500 \mathrm{mg} \mathrm{L}^{-1}\right)$ were mixed in conical flask $(24 \mathrm{~h})$, at 25,35 and $45^{\circ} \mathrm{C}$. For the kinetic studies, $0.2 \mathrm{~g}$ of adsorbents was added to $100 \mathrm{ml}$ of dye solutions $\left(500 \mathrm{mg} \mathrm{L}^{-1}\right)$. The amount of the adsorbed dye at equilibrium was calculated as follows:

$$
q_{e}=\frac{\left(C_{o}-C_{e}\right) \cdot V}{m}
$$

Where $\mathrm{C}_{0}$ and $\mathrm{C}_{\mathrm{e}}\left(\mathrm{mg} \mathrm{L}^{-1}\right), V(L)$ and $m(g)$ are the initial and equilibrium dye concentrations in liquid phase, the volume of the treated solution and the weight of the adsorbent, respectively.

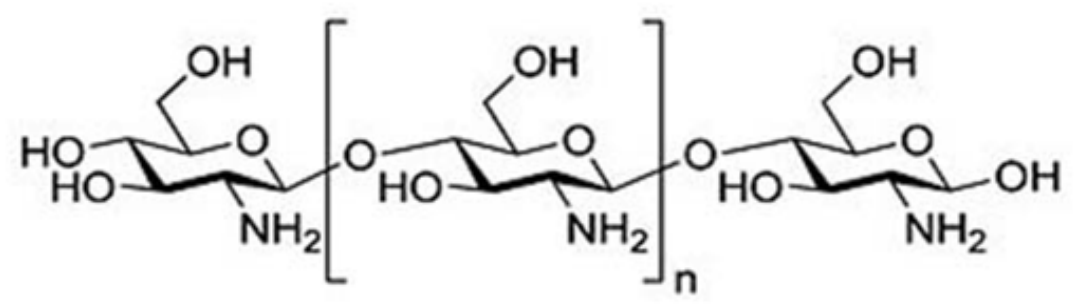

Figure 1. Chemical structure of chitosan.

Desorption of AR from adsorbents were studied at 25,35 and $45^{\circ} \mathrm{C}$. At $\mathrm{pH}=3$, adsorbate/ adsorbent samples were shacked with $100 \mathrm{ml}$ of double distilled water in thermostatic shaker bath.

\section{Results and discussion}

Effect of experimental parameters on dyes adsorption

For CC/AR183, CC/AR114, CP/AR183, CP/AR114, PAC/AR183 and PAC/AR114, same $\mathrm{S}$-form $\mathrm{q}_{\mathrm{e}}=\mathrm{f}(\mathrm{pH})$ curves have been obtained, evidencing three distinct shapes. A notably increasing of the amount of the adsorbed dye has been observed until $\mathrm{pH}=3$, which corresponds to the optimum dye removals. The amino groups of chitosan are protonated and interact with sulfonyl groups of anionic dyes to form organic complex $\left(\mathrm{NH}_{3}{ }^{+}{ }^{-} \mathrm{O}_{3} \mathrm{SR}\right)^{22,23}$, while more active acidic surface groups of PAC, such as carboxyl and lactone, facilities electrostatic interactions ${ }^{7,8,24,25}$. 


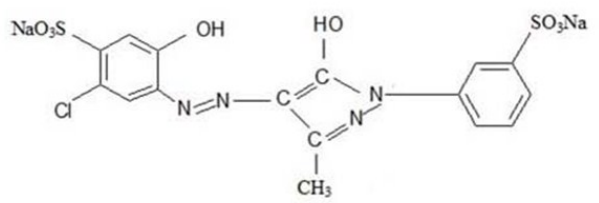

(a) AR 183

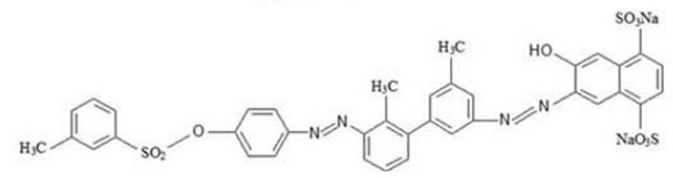

(b) AR 114

Figure 2. Molecular structures of (a) AR183, (b) AR114.

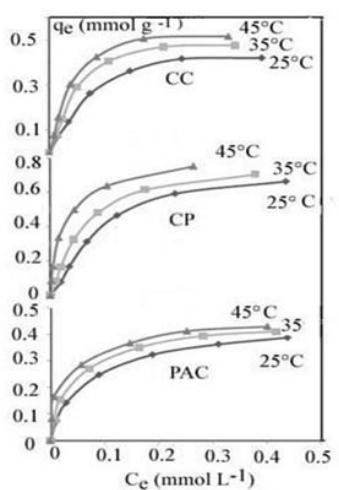

(a)

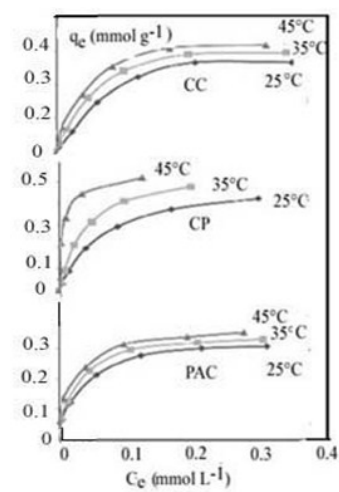

(b)

Figure 3. The adsorption curves of (a) AR 183 and (b) AR114 dyes onto adsorbents.

As expected for the effect of adsorbent dose, the equilibrium uptakes of dye present optimum values for $0.1 \mathrm{~g}$ of adsorbents ${ }^{4,26}$. Besides, the efficiency increases with temperature indicating endothermic incorporations of dyes into adsorbents, which could be considered as chemical adsorption ${ }^{27}$.

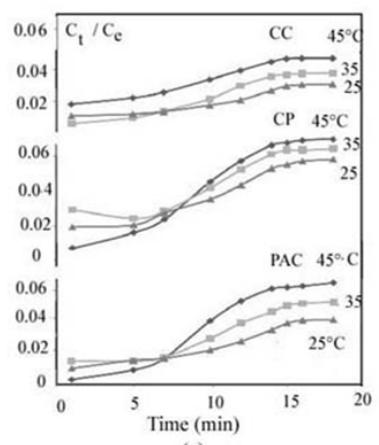

(a)

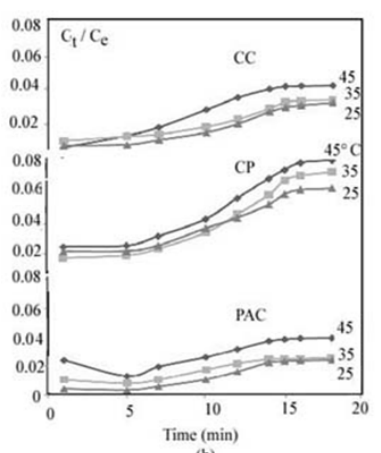

(b)

Figure 4. Desorption profiles of (a) AR 183 and (b) AR114 onto adsorbents $\left(C_{t}\right.$ : the amount of dye adsorbed at any time). 


\section{Equilibrium modeling}

The isotherms profiles of all adsorbent/ adsorbate couples show same shapes (Fig.3), with concavities and regular values. The equilibrium uptake increases with the initial dye concentration and the temperature, confirming the establishment of endothermic processes. Besides, the incorporation of both two kind of $\mathrm{AR}$ rises in the order $\mathrm{PAC}<\mathrm{CC}<\mathrm{CP}$. This difference could be explained by the surface and micropore-macropore areas, structure and active sites dissimilarity. At the optimum conditions, the highest adsorption capacity is determined for CP/ AR183 couple (446.75 $\mathrm{mg} \mathrm{g}^{-1}$ ), while the lowest one is obtained for $\mathrm{CC} / \mathrm{AR} 183$ (301.59 $\mathrm{mg} \mathrm{g}^{-1}$ ). Since these biomaterials have similar DD\%, this difference could be assigned to the effect of their molecular weights ${ }^{4}, 550 \mathrm{~g} \mathrm{~mol}^{-1}$ for CP and $340 \mathrm{~g}$ $\mathrm{mol}^{-1}$ for CC. The degree of the adsorption of AR 183 and 114 are less important than this of Acid Orange $12\left(973.3 \mathrm{mg} \mathrm{g}^{-1}\right)$, which is a smallest molecule and has only one sulfonated acid group ${ }^{4}$. In the literature, the difference in the degree of adsorption have be assigned to the molecular size or/and the number of sulphonate groups ${ }^{16}$. For AR 183 and AR114, the deeper penetration of the former dye into the internal pore structure of chitosan could be explained by its smallest molecule.

In order to describe the biosorption equilibrium, the experimental data were fitted to Langmuir $^{28,29}$, Freundlich ${ }^{30}$, Temkin ${ }^{26}$ and generalized models ${ }^{31}$. To select of the most suitable one, the sums of the squares of errors between experimental and predicted values of qe (Eq.3) were estimated ${ }^{16}$.

$$
S S E=\sum_{i=1}^{p}\left(q_{e, \text { calc }}-q_{e, \text { meas }}\right)_{i}^{2}
$$

The obtained results indicate that the most satisfactory equation is the Langmuir model (Eq. 4), which corresponds to the lowest SSE values indicating monolayer adsorption process and constants adsorption energy (Table.1). This fact may be due to homogeneous distribution of active sites on the material.

$$
q_{e}=\frac{K_{L} C_{e}}{1+a_{L} C_{e}}
$$

$\mathrm{C}_{\mathrm{e}}\left(\mathrm{mmol} \mathrm{L}^{-1}\right)$ and $\mathrm{q}_{\mathrm{e}}\left(\mathrm{mmol} \mathrm{g}^{-1}\right)$ are the liquid and solid phase concentration of the adsorbate at equilibrium, respectively. $\mathrm{K}_{\mathrm{L}}\left(\mathrm{L} \mathrm{g}^{-1}\right)$ and $\mathrm{a}_{\mathrm{L}}\left(\mathrm{L} \mathrm{mg}^{-1}\right)$ are the Langmuir isotherm constants. $Q_{\max } / m g g^{-1}=K_{L} / a_{L}$ is a characteristic constant of the occupied area, which reflects the limited adsorption capacity. 
Table 2. Pseudo second-order rate constant, calculated and experimental $\mathrm{q}_{\mathrm{eq}}$ values obtained for initial AR concentration of $500 \mathrm{mg} \mathrm{L}^{-1}$.

\begin{tabular}{cccccccc}
\hline & & \multicolumn{3}{c}{$\mathrm{AR} 183$} & & $\mathrm{AR} 114$ \\
& & $25^{\circ} \mathrm{C}$ & $35^{\circ} \mathrm{C}$ & $45^{\circ} \mathrm{C}$ & $25^{\circ} \mathrm{C}$ & $35^{\circ} \mathrm{C}$ & $45^{\circ} \mathrm{C}$ \\
\hline & $\mathrm{C}_{0}\left(\mathrm{mg} \mathrm{L}^{-1}\right)$ & 497 & 482.1 & 498.1 & 483.1 & 501.2 & 500.7 \\
& $\mathrm{q}_{\mathrm{e}, \text { exp }}\left(\mathrm{mg} \mathrm{g}^{-1}\right)$ & 245.908 & 278.284 & 301.586 & 255.1 & 278.311 & 297.588 \\
$\mathrm{CC}$ & $\mathrm{K}_{\mathrm{II}}$ & 9.333 & 10.8 & 18.166 & 10.8 & 12.675 & 20.333 \\
& $\mathrm{q}_{\mathrm{e}, \text { cal }}\left(\mathrm{mg} \mathrm{g}^{-1}\right)$ & 243.902 & 277.777 & 303.03 & 256.41 & 277.777 & 285.741 \\
& $\mathrm{R}^{2}$ & 0.9995 & 0.9997 & 0.9998 & 0.9997 & 0.9997 & 0.9999 \\
\hline & $\mathrm{C}_{0}\left(\mathrm{mg} \mathrm{L}^{-1}\right)$ & 497.5 & 499.5 & 502.2 & 489.4 & 500.1 & 501.2 \\
& $\mathrm{q}_{\mathrm{e}, \text { exp }}\left(\mathrm{mg} \mathrm{g}^{-1}\right)$ & 367.388 & 412.611 & 446.755 & 388.544 & 412.336 & 439.818 \\
$\mathrm{CP}$ & $\mathrm{K}_{\mathrm{II}}$ & 4.033 & 6.533 & 10.416 & 5.216 & 5.633 & 8.833 \\
& $\mathrm{q}_{\mathrm{e}, \text { cal }}\left(\mathrm{mg} \mathrm{g}^{-1}\right)$ & 357.142 & 400 & 454.545 & 384.615 & 400 & 434.782 \\
& $\mathrm{R}^{2}$ & 0.9997 & 0.9997 & 0.9992 & 0.9993 & 0.9987 & 0.9997 \\
\hline & $\mathrm{C}_{0}\left(\mathrm{mg} \mathrm{L}^{-1}\right)$ & 482.3 & 483.4 & 485.5 & 481.1 & 483.4 & 483.7 \\
& $\mathrm{q}_{\mathrm{e}, \text { exp }}\left(\mathrm{mg} \mathrm{g}^{-1}\right)$ & 226.576 & 239.386 & 250.83 & 210.877 & 228.122 & 243.09 \\
$\mathrm{PAC}$ & $\mathrm{K}_{\mathrm{II}}$ & 7.35 & 8.883 & 16.883 & 6.35 & 8.166 & 10 \\
& $\mathrm{q}_{\mathrm{e}, \text { cal }}\left(\mathrm{mg} \mathrm{g}^{-1}\right)$ & 222.222 & 239.095 & 250 & 208.333 & 227.272 & 243.902 \\
& $\mathrm{R}^{2}$ & 0.9992 & 0.9982 & 0.9981 & 0.9999 & 0.994 & 0.9998 \\
\hline
\end{tabular}

Kinetic modeling

Pseudo-first order and pseudo-second order models ${ }^{32-35}$ are usually used, for selecting the optimum operating conditions. For all couples, the kinetics of the adsorption fit well with the pseudo-second order model (Eq. 8), which predicts chemical adsorption involving valency force.

$$
\frac{t}{q}=\frac{1}{q_{e}^{2} K_{I I .}}+\frac{1}{q_{e}} t
$$

$q_{e}$ and $q\left(\mathrm{mg} \mathrm{g}^{-1}\right)$ and $K_{\mathrm{II}}\left(\mathrm{g} \mathrm{mg} \mathrm{min}^{-1}\right)$ are the amounts of the adsorbed dye (at equilibrium and after variable time contact) and the second order kinetic rate constant, respectively. $K_{\mathrm{II}}$ shows augmentation with the AR concentration and the temperature. These kinetics funding were in agreement with chemisorption rate controlling step ${ }^{36-38}$.

Table 3. Standard thermodynamic constants of AR/Adsorbent systems.

\begin{tabular}{c|c|c|c}
\hline Systems & $\Delta \mathrm{G}^{\circ}\left(\mathrm{KJ} \mathrm{mol}^{-1}\right)$ & $\Delta \mathrm{H}^{\circ}\left(\mathrm{KJ} \mathrm{mol}^{-1}\right)$ & $\Delta \mathrm{S}^{\circ}\left(\mathrm{KJ} \mathrm{mol}^{-1} \mathrm{k}^{-1}\right)$ \\
\hline AR183/CC & -4.796 & 32.63 & 0.125 \\
\hline AR183/CP & -6.72 & 75.555 & 0.275 \\
\hline AR183/ PAC & -4.846 & 45.273 & 0.169 \\
\hline AR114/CC & -5.42 & 26.45 & 0.108 \\
\hline AR114/CP & -6.64 & 64.84 & 0.239 \\
\hline AR114/PAC & -5.54 & 35.19 & 0.136 \\
\hline
\end{tabular}




\section{Thermodynamic modeling}

The degree of spontaneity of the process could be indicated by Gibbs free energy, using the following equation ${ }^{39}$ at $25^{\circ} \mathrm{C}$ :

$$
\Delta G^{\circ}=-R T \ln k_{L}
$$

where $\mathrm{R}, \mathrm{T}$ and $\mathrm{k}_{\mathrm{L}}$ are universal gas constant, temperature $(\mathrm{K})$ and Langmuir equilibrium constant, respectively.

The enthalpy change $\left(\Delta \mathrm{H}^{\circ}\right)$ and the entropy change $\left(\Delta \mathrm{S}^{\circ}\right)$ can be determined using the van't Hoff equation:

$$
\ln K_{L}=\frac{\Delta S^{\circ}}{R}-\frac{\Delta H^{\circ}}{R T}
$$

The thermodynamic characteristics could be estimated by determining the isotherms of the studied dye/adsorbent systems at different temperatures. In Table 3, the negative values of $\Delta \mathrm{G}^{\circ}$ at $25^{\circ} \mathrm{C}$ indicate that all the adsorption processes are spontaneous in nature, with high degrees of affinity of dye molecules for each adsorbent surface. The positive values of $\Delta \mathrm{H}^{\circ}$ suggest endothermic nature of adsorption. These results could be explained by strong bonding between dye and adsorbent. For $\Delta \mathrm{S}^{\circ}$, the positive values reflect affinities of solid materials for $A R$ and their structural changes. The highest negative values of $\Delta G^{\circ}$ is obtained for $\mathrm{CP} / \mathrm{AR} 183\left(-6.72 \mathrm{~kJ} \mathrm{~mol}^{-1}\right)$. The difference in the thermodynamic characteristics between the adsorption process of CP/AR183 and CP/AR114 could be assigned to the dissimilarity of the chemical structures of dyes. In addition, CP shows the highest positive values of $\Delta \mathrm{H}^{\circ}$ and $\Delta \mathrm{S}^{\circ}$, indicating that the most endothermic process corresponds to this adsorbent, which exhibits the highest increasing in randomness at solid /solution interface. Significant changes would occur in the internal structure of CP and dyes through the attachment of adsorbates ${ }^{40}$.

\section{Desorption studies}

The nature of the adsorption process can also be elucidate by desorption studies ${ }^{41}$. In acidic medium, the kinetic curves show similar shapes with three periods of AR releases (Fig. 4). In the first one, slow deliveries take place; the amounts of dye desorbed are low. This behavior can be attributed to the fact that the main portion of the adsorbed dyes is chemically included in the adsorbents. In the second period (7-13 $\mathrm{min})$, rapid releases are observed, which reach approximately $10 \%$ of the incorporated AR. After $13 \mathrm{~min}$, desorption became independent to time, indicating a zero order kinetic processes. Lower percentages of acid dyes are eliminated from all adsorbents, confirming a strong interaction between $\mathrm{SO}_{3}^{-}$ group in $\mathrm{AR}$ (Fig.2) and $\mathrm{NH}_{3}^{+}$group in chitosan (Fig.1). Besides, the released quantities decrease from 25 to $45^{\circ} \mathrm{C}$, suggesting the favorability of the adsorption processes at high temperature. These results confirm the chemisorption processes based on electrostatic attraction between the protonated amino cations and the sulfonate anions (scheme.1). 


$$
\begin{aligned}
& \mathrm{R}-\underset{\mathrm{CP}}{\mathrm{NH}_{2}} \underset{\text { protonation }}{\stackrel{\mathrm{H}^{+}}{\longrightarrow}} \mathrm{R}-\mathrm{CPH}^{+} \mathrm{NH}_{3}^{+} \\
& \mathrm{R}^{\prime}-\mathrm{SO}_{\mathrm{AR}} \mathrm{Na} \underset{\text { dissociation }}{\stackrel{\mathrm{H}_{2} \mathrm{O}}{\rightleftarrows}} \mathrm{R}^{\prime}-\mathrm{SO}_{3}^{-}+\mathrm{Na}^{+} \\
& \mathrm{R}-\mathrm{CPH}^{+} \mathrm{NH}_{3}^{+}+\mathrm{R}^{\prime}-\mathrm{SO}_{3}^{-} \underset{\text { Electrostaticinteraction }}{\underset{\mathrm{S}}{(}} \mathrm{R}-\mathrm{NH}_{\text {CPAR }}^{+-} \mathrm{O}_{3} \mathrm{~S}-\mathrm{R}^{\prime}
\end{aligned}
$$

\section{Scheme 1}

\section{Conclusion}

Chemisorption processes based on electrostatic interaction between protonated amino groups of CP and CC and anionic sulfonate group of dye are suggested for the adsorption of AR 183 and AR114 onto chitosan. By this comparative study, we could assume that the molecular weight of chitosan, as well as the structure of textile dye, is important for the adsorption process. The efficiency of dye removal increases with the first factor, indicating the availability of more important site surface in adsorbent for the attachment of dye. Finally, highest uptake is obtained for the smallest dye molecule.

\section{Acknowledgements}

This work was supported by the Tunisian Ministry of H. E. Sc. R. and the Saudi K. S. University.

\section{References}

1. Attia A A, Rashwan W E and Khedr S A. Dyes. Pig 2006, 69, 128-136.

2. Clarke E A and Anliker R, Organic dyes and pigments: Handbook of environmental chemistry; anthropogenic compounds: New York: springer-Verlag, 1980.

3. Wong Y and Jian Yu. Water. Res 1999, 33, 3512.

4. Grini G and Badot P-M. Prog. Polym. Sci 2008, 33, 399.

5. Vandevivere P C, Bianchi R and Verstraete W. J. Chem. Tech . Biotech 1998, 72, 289.

6. Ganesh R, Boardman G D, Michelsen D. Water. Res 1994, 28,1367.

7. Tolaimate A, Desbrieres J, Rhazi M and Alagui A. Polym 2003, 44, 7939.

8. Aksu Z, Tatli A İ and Tunç Ö. J. Chem. Eng 2008, 142, 23-39.

9. Crini G. J. Biores._Technol 2006, 97, 1061.

10. Annadurai G, Ling L Y and Lee J-F. J. Hazard. Mater 2008, 152, 337.

11. Chiou M-S and Chuang G-S. Chemosphere 2006, 62, 731.

12. Ahmad A L, Sumathi S and Hameed B H. Water. Res 2005, 39,2483.

13. Wu F C, Tseng R L and Juang R S. J. Hazard. Mater 2000, 73, 63.

14. Chiou, M.S., Ho, P.Y and Li, H.Y. Dyes. Pig 2004, 60, 69-84. 
15. Davis T A, Volesky B and Mucci, A. Water. Res 2003, 37, 4311.

16. Wong Y C, Szeto Y S, Cheung W H and Mckay, G. Pro. Biochem 2004, 39, 693-702

17. Guibal E. Sep Pur_Technol 2004, 38, 43-74.

18. Crini G. J. Prog. Polym. Sci 2005, 30, 38-70.

19. Varma A J, Deshpande S V and kennedy J F. J. Carbohy. Polym 2004, 55, 77-93.

20. Monteiro Jr, O A C and Airoldi C. J. Colloid. Interf. Sci 1999, 212, 212.

21. Sabnis S and Block L H Polym Bull 1997,39, 67-71.

22. Uzun İ. Dyes. Pig 2006, 70, 76-83.

23. Guibal E, Mc-Carrick P and Tobin J M. Sep. Sci. Technol 2003, 38, 3049.

24. Özacar M and Sengil I A. Adsorption 2002, 8, 301.

25. Hoda N, Bayram E and Ayranci E. J. Hazard. Mater 2006, 137,344.

26. Crini G, Martel B and Torri G. Int. J. Environ. Pollut 2008, 34, 451.

27. Aksu Z and Tezer S. Pro. Biochem 2000, 36, 431.

28. Park R D, Cho Y Y, Kim K Y, Bom H S and Oh C S, Lee H C. Agr. Chem. Biotechnol $1995, \mathbf{3 8}, 447$.

29. Langmuir I. J. Am. Chem. Soc 1918, 40, 131403.

30. Freundlich H. Phys Chem Soc 1906; 40: 1361-1368.

31. kargi F and Ozmihci S. Enzyme. Micr. Technol 2004, 35, 267.

32. Aksu Z and Tezer S. J. Pro._Bioch 2005,40, 1347.

33. Ho Y S and Mckay G. Water. Res 2000, 34, 735.

34. Kumar K V, Sivanesan S and Ramamurthi V. J. Pro. Biochem 2005, 40, 2865.

35. Akkaya G, Uzun İ and Güzel F.Dyes._Pig_2007, 73, 168.

36. Ng J C Y, Cheung W H and Mckay G. J. Colloid. Interface. Sci 2002, 255, 64.

37. Mckay G and Ho Y S. Pro. Biochem 1999, 34, 451.

38. Mckay G and Ho Y S. Water. Res 1999, 33, 578-584.

39. Eren Z and Acar F N. J. Hazard. Mater 2007, 143, 226.

40. Bekçi Z, Özveri C, Seki Y and Yardakoç k. J. Hazard. Mater 2008, 154, 254.

41. Adamson A W, Physical chemistry of surface, Interscience Publishers Inc: New York, 1960 . 


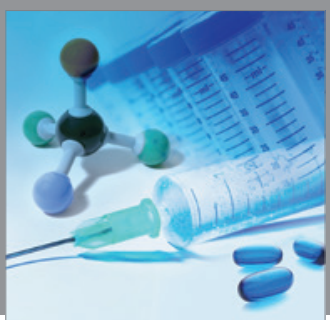

International Journal of

Medicinal Chemistry

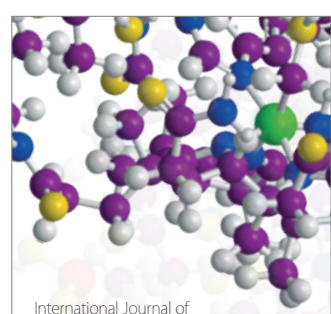

Carbohydrate Chemistry

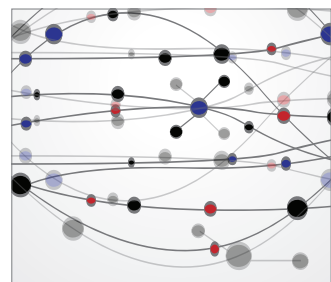

The Scientific World Journal
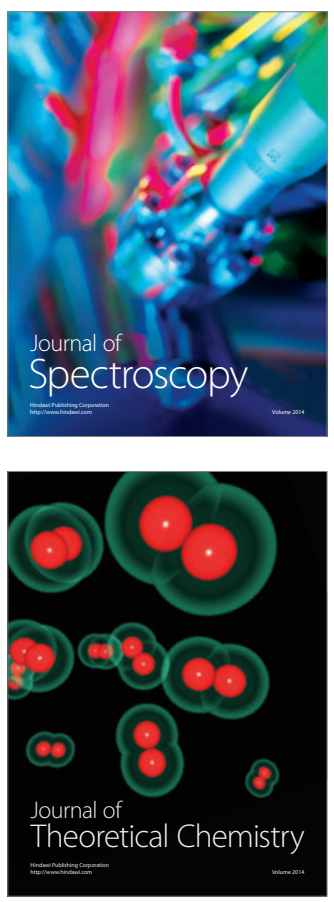
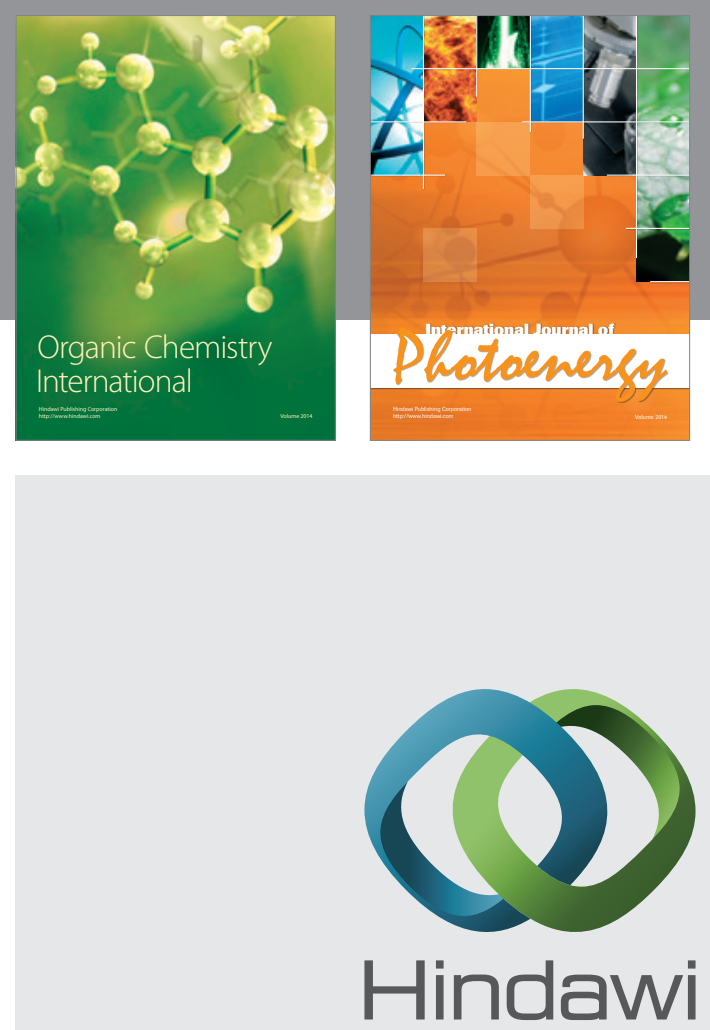

Submit your manuscripts at

http://www.hindawi.com
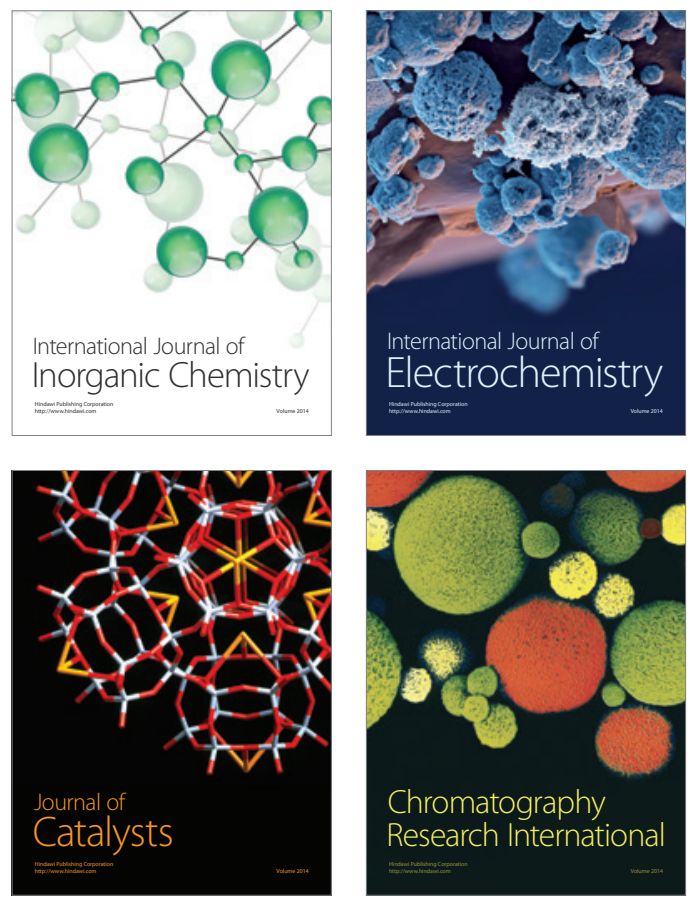
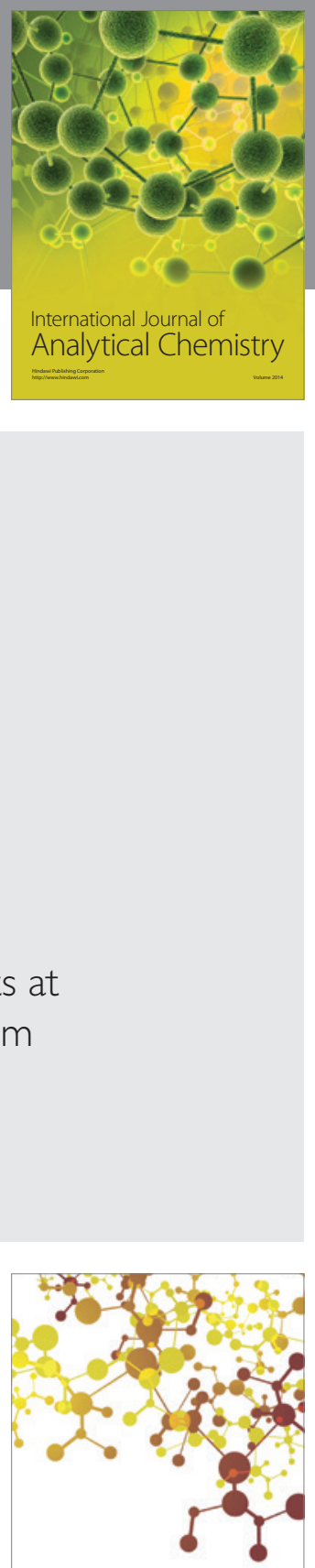

Journal of

Applied Chemistry
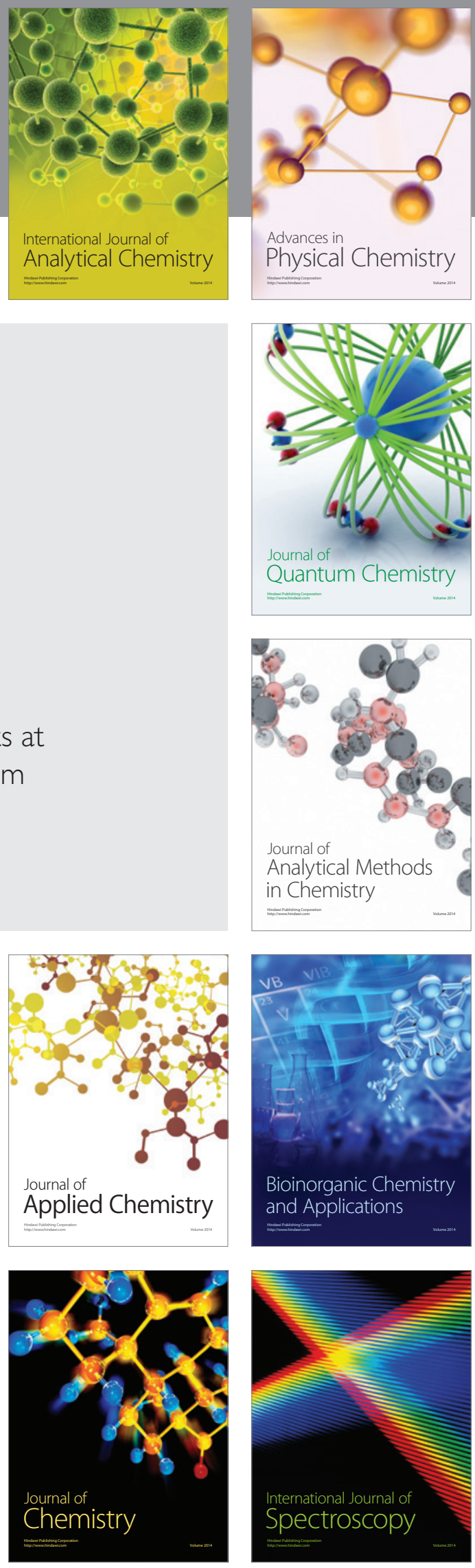